\title{
Influence of Orthopaedic Drilling Parameters on Surface Roughness and Cutting Force of Bone Drilling Process
}

\author{
R. Izamshah ${ }^{1}$, M.S Noorazizi ${ }^{1}$, M.S Kasim ${ }^{1, *}$ and C.H Che Haron ${ }^{2}$ \\ ${ }^{1}$ Faculty of Manufacturing Engineering, Universiti Teknikal Malaysia Melaka, Hang Tuah Jaya \\ 76100, Durian Tunggal, Melaka, Malaysia \\ ${ }^{2}$ Faculty of Engineering and Built Environment, Universiti Kebangsaan Malaysia \\ 43600, UKM, Bangi, Selangor, Malaysia \\ *Engr.nms801@gmail.com
}

Keyword: Bone drill-bit; Surface Roughness; Cutting Force; Machining; Response Surface Method

\begin{abstract}
In orthopaedic surgery internal fixation of bone fractures using immobilization screws and plate is common procedure. This surgical procedure involved drilling into bone and fixative components interaction. Many problems are encountered with the bone drilling process such as holes accuracy, drill wander and excessive heat generation which were directly related with the drilling parameter. This paper investigates the effect of drilling parameter namely spindle speed and feed rate on the cutting force and surface roughness performance. Design of Experiment (DOE) historical data of Response Surface Method (RSM) were adopted to evaluate the correlation between the cutting parameter and the holes performance. From the conducted investigation, the most significant parameter that affect the holes performance was spindle speed followed by the feed rate. In addition, the interaction between feed rate and spindle speed also controlled the holes performances.
\end{abstract}

\section{Introduction}

Bone drilling is one of the major procedures in orthopaedic surgery for fixation. Close tolerances and surface finish of the drilled bone are critical for the osseointegration ability [1-3]. The surface characteristic affects the bone-screw interface strength as well as the cellular response, which is essential for early and healthy bone growth. Various techniques were employed to enhance bone apposition including bioactive coating and surface texturing of fixative components. Surface rougheness is one of the methods to enhanced bone growth during the healing process with promising result [11-12]. There has been ongoing research associated with implant surface topography. Proper mating between two joining surfaces are necessitated for a stable bone-implant interface in minimizing the trauma due to the drilling forces [4]. The drilling conditions in bone drilling process are interrelated by rotational speed and the feed rate which affect the drilling forces and holes qualities. Hence, the understanding on the effects of drilling parameter on the hole performances are necessitate.

Response surface methodology (RSM) is widely used in process optimization and modelling [5]. This method was proved effectively and widely used in the process of industrialization. The optimized response is influenced by a few of cutting parameters as input variables. In order to convert the independent variable to see the changes of the output response, a series of tests called run was conducted to see the response based on the selecting factors. In order to study the relationship between bone drilling process parameters and the holes performances, a systematically approach design of experiments (DOE); response surface method (RSM) can be used effectively. Kasim et al. [6] demonstrated RSM able to predict surface roughness value with less error. This paper aim to investigate the effects of drilling parameter on holes performance namely surface roughness and drilling force for bone drilling using RSM technique. 


\section{Experimental}

Experimental Setup. Set of experiments were conducted to investigate the effect of high speed drilling on cutting force and surface roughness. Each test was performed using a HAAS VF-1 CNC Vertical Machine. A Kistler type 9275BA dynamometer was mounted under the work piece fixture to record the thrust force during the process (see Fig. 1, Fig. 2).

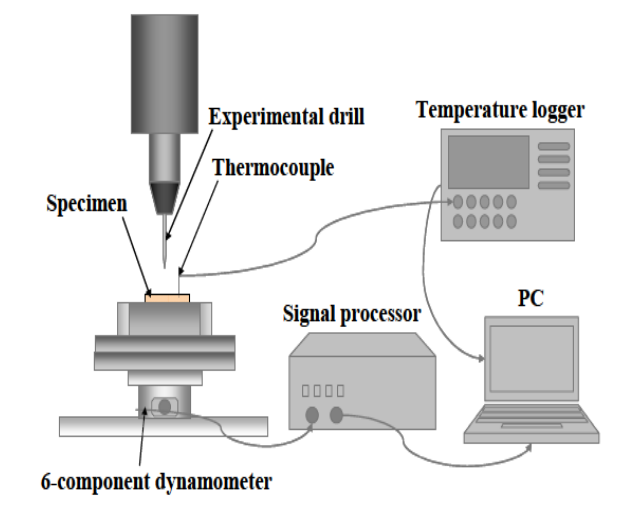

Figure 1. Experimental setup for bone drilling.

Before conducting experiments CNC machine will run without load at least 30 minutes. At the same time clamping will be checked to ensure that work is neatly sandwiched in the clamped area. This is to prevent that from happening any collision during the machining process. A machining blank expression process will be done on offset at $\mathrm{z}$ axis during the motion and will be ensured fast controlled independent work of earlier machines such as depth and roughness effects on the process of running is free. One of the size using the current size parameter is done by using the tool is not counted in the calculation of wear and then found that the actual machining and processing performed each time a change cutting parameters.

Dynamometer are used to measure both the torque and the thrust force [7, 14]. During the operation take place the sample of bovine bone is clamped on the worktable of a sensitive drilling dynamometer that are this machine are able to taking $25 \mathrm{~mm}$ height and length up to $300 \mathrm{~mm}$. The surface roughness of drilled holes was measured by Mitutoyo Roughness Tester.

Material Specimen. Bovine cortical femur bone is chosen as the work material due to its closeness properties and characteristics with human bone [4]. Table 1 shows the mechanical properties of bovine femur. The mid-diaphysis columns were obtained with the average length of 75 $\mathrm{mm}$ for the experiments. The average thickness of the cortical wall was 6-8 $\mathrm{mm}$. Periosteum were removed from the drilling surface prior to the experiment to avoid the chips clogging. The specimens were cut precisely by the milling machine with approximately $15 \mathrm{~mm}$ in width as shown in Fig. 3. All experiments were conducted in a room temperature without using any coolant and lubricant.

Table I Mechanical properties of bovine femur.

\begin{tabular}{lc}
\hline Mechanical properties & Value \\
\hline $\begin{array}{l}\text { Density (kg/m3) } \\
\text { Young's modulus (MPa) }\end{array}$ & 1800 \\
$\begin{array}{l}\text { Longitudinal elastic modulus } \\
\text { (GPa) }\end{array}$ & 20000 \\
$\begin{array}{l}\text { Transverse elastic modulus } \\
(\mathrm{GPa})\end{array}$ & 10.9 \\
$\begin{array}{l}\text { Longitudinal tensile strength } \\
\text { (MPa) }\end{array}$ & 140 \\
$\begin{array}{l}\text { Transverse tensile strength } \\
\text { (MPa) }\end{array}$ & 46 \\
Poisson's ratio & 0.36 \\
\hline
\end{tabular}




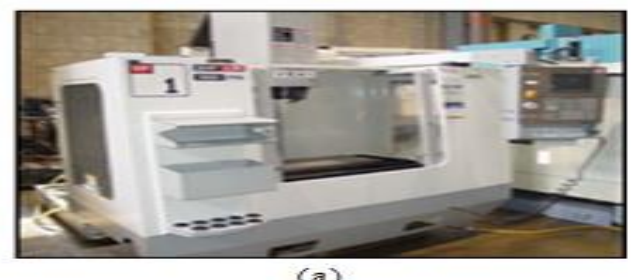

(a)
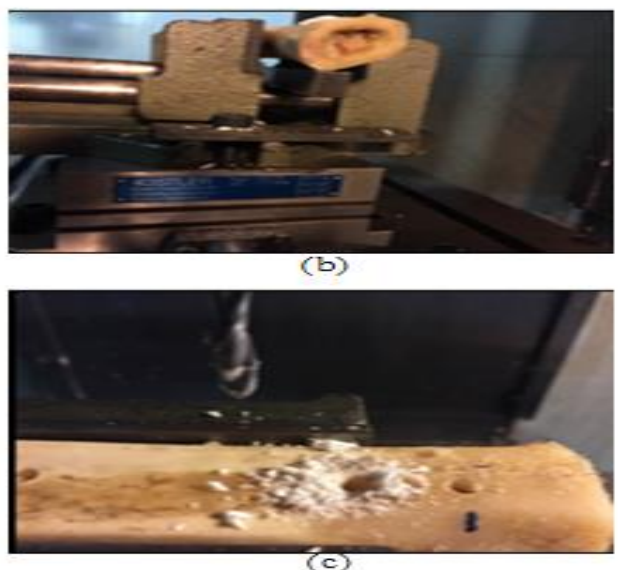

Figure 2. Experimental setup for bone drilling.

(a) HAAS VF-1 CNC Vertical Machine (b) Kistler type 9275BA, (c) Drilling operation.
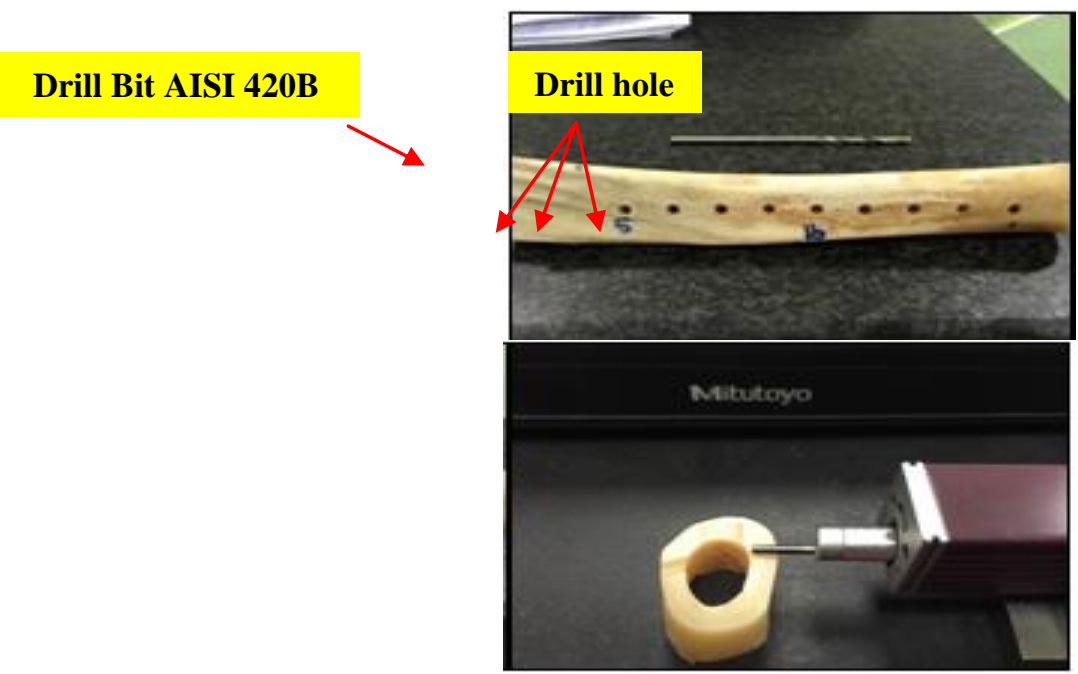

Figure 3. (a) Fresh Bovine Femur with Drill-Bit and (b) The Sample cut from the bone with surface roughness equipment.

In this experiment, two flutes with $4.3 \mathrm{~mm}$ diameter medical surgical drill-bit (AISI 420B stainless steel) was used to drill the bovine cortical femur bone. Fig. 4 and Table 2 depicted details specification of the drill bit. The medical surgical drill-bit were employed because of its accurate drilling and deliver consistent rotational movement during the process. In addition, stainless steel drill bit exhibits good corrosion resistance. Besides that, by using stainless steel drill bit, it can minimize the tool wear effect. Totals of 80 holes were drilled with 10 holes replication for each run. To elliminate the apparatus wear impact on the result, the boring apparatus were cleaned with a brush and wet tissue before each drilling process. 


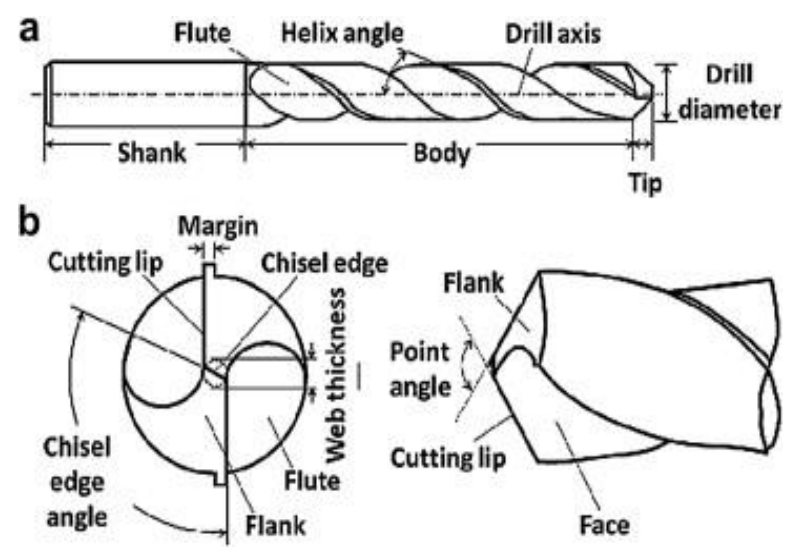

Figure 4. Drill bit specification

Table 2 Drill geometry parameter

\begin{tabular}{|c|c|}
\hline Drill diameter $(\mathrm{mm})$ & 4.3 \\
\hline Web thickness $(\mathrm{mm})$ & 2.364 \\
\hline Helix angle $\left(^{\circ}\right)$ & 19.07 \\
\hline Point angle $\left(^{\circ}\right)$ & 96.04 \\
\hline Margin $(\mathrm{mm})$ & 0.284 \\
\hline Clearance $(\mathrm{mm})$ & 0.358 \\
\hline
\end{tabular}

Experimental Matrix. Two factors were selected for this experiment. There are spindle speed and feed rate with two levels as shown in Table 3. Then, the process control parameters and their limit was substitute into Design Expert version 6.0 software. By applying RSM, the planning matrix will contain the value exceeds the $(-1)$ or $(+1)$ range to allow estimation of curvature. The lower limit for low (-1) was added for spindle speed $(550 \mathrm{rpm})$ and feed rate $(20 \mathrm{~mm} / \mathrm{min})$. While the upper limit for $(+1)$ was added for spindle speed $(1550 \mathrm{rpm})$ and feed rate $(95 \mathrm{~mm} / \mathrm{min})$. By increasing drill rotational speed (especially at higher speeds range,), drilling thrust force decreases considerably $[8,9]$.

Table 3 Process control parameters and levels

\begin{tabular}{cccc}
\hline \multirow{2}{*}{ Factors } & Parameters & Limit & Limit \\
& & -1 & 1 \\
\hline A & Spindle Speed $(\mathrm{mpm})$ & 600 & 1500 \\
B & Feed Rate $(\mathrm{mm} / \mathrm{min})$ & 25 & 85 \\
& & & \\
\hline
\end{tabular}

\section{Result and Discussion}

From the conducted investigations, it is evident that drilling parameters (spindle speed and feed rate) are important criteria that affect the hole performances namely surface roughness and force magnitude. Experimental result of surface roughness for drilling process is shown in Table 4. From the result, it the minimum of surface roughness is $0.736 \mu \mathrm{m}$ and the maximum is $3.43 \mu \mathrm{m}$. The result of cutting force is $7.459 \mathrm{~N}$ and the maximum is $19.785 \mathrm{~N}$. 
Table 4 DOE result for surface roughness and cutting force for bone drilling process

\begin{tabular}{cccccc}
\hline Standard & Run & $\begin{array}{c}\text { Factor A } \\
\text { Spindle Speed } \\
(\mathrm{rpm})\end{array}$ & $\begin{array}{c}\text { Factor B } \\
\text { Feed Rate } \\
(\mathrm{mm} / \mathrm{min})\end{array}$ & $\begin{array}{c}\text { Surface } \\
\text { Roughness } \\
(\mu \mathrm{m})\end{array}$ & $\begin{array}{c}\text { Force } \\
(\mathrm{N})\end{array}$ \\
\hline 7 & 1 & 600 & 25 & 0.753 & 7.459 \\
8 & 2 & 1500 & 85 & 0.883 & 19.785 \\
6 & 3 & 1500 & 25 & 1.51 & 12.076 \\
3 & 4 & 1500 & 85 & 1.25 & 12.853 \\
4 & 5 & 600 & 85 & 0.736 & 11.236 \\
1 & 6 & 1500 & 25 & 1.9 & 11.846 \\
2 & 7 & 600 & 25 & 1.39 & 8.66 \\
5 & 8 & 600 & 85 & 3.43 & 10.618 \\
\hline
\end{tabular}

Equation 1 and 2 show the mathematical relationship for correlating the surface roughness and cutting forces considering output responses of drilling parameters, i.e. spindle speed and feed rate. The mathematical model was obtained from using design expert software. "Adeq Precision" measures the signal to noise ratio. A ratio greater than 4 is desirable thats meaning indicates an adequate signal [13-14]. The prediction model can be denoted by equation as:

$$
\begin{aligned}
& \text { Surface Roughness }(\mu \mathrm{m})=1.006+5.692 \times 10^{-4} \text { Speed }-8.622 \times 10^{-3} \text { Feed rate } \\
& \text { Force }(N)= \\
& 5.641+2.040 \times 10^{-3} \text { Speed }-7.28110^{-3} \text { Feed rate }+9.17910^{-5} \text { Speed } * \text { Feed rate }
\end{aligned}
$$

The two factors A and B have large positive effect. Fig. 3(a) and (b) show the interaction factor plot for spindle speed and feed rate towards surface roughness and cutting forces. Surface roughness increases as a cutting speed increases but poor ra when fz $25 \mathrm{~mm} / \mathrm{min}$. The effect of the primary machining parameters on surface roughness was found to be comparable with that reported by $[9,10]$. The interaction graph shows that by increasing the speed the cutting force also increases but the cutting forces more sensitive when federate $85 \mathrm{~mm} / \mathrm{min}$ rather than $25 \mathrm{~mm} / \mathrm{min}$. It was indicated by the steep trend of the interaction factor shows the performances of machining parameters of the bone drilling.
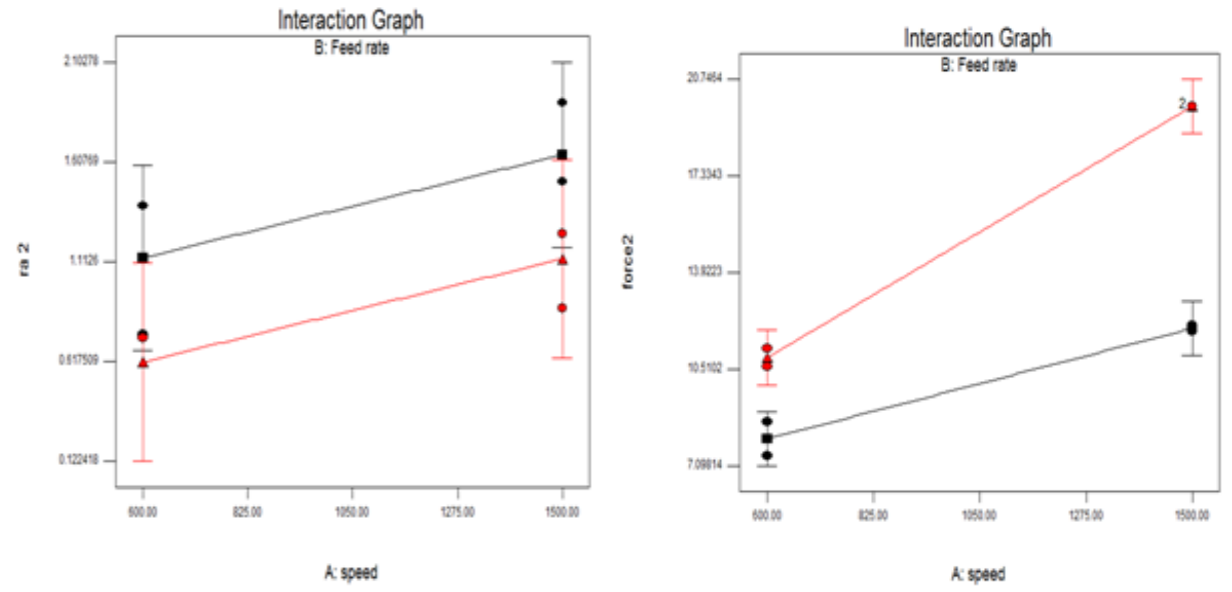

Figure 5. Interaction factor plot for (a) Surface Roughness and (b) Cutting Forces

\section{Conclusions}

Investigations of high performances surgical drill-bit bone analysis using Response Surface Method (RSM) historical data were studied. Surface roughness and cutting force were measured for each experimental state. The following conclusion can be drawn as follows: 
- This study demonstrated the interaction effect of drilling parameters on surface roughness and cutting force of drilling hole of femur bovine bone using RSM. The interaction between the feed rate and the spindle speed significantly affect the surface roughness and the cutting force.

- From the result, the minimum of surface roughness is $0.736 \mu \mathrm{m}$ and the maximum is $3.43 \mu \mathrm{m}$. The result of cutting force is $7.459 \mathrm{~N}$ and the maximum is $19.785 \mathrm{~N}$. By increasing drill spindle speed (at higher speeds range, especially), drilling cutting force increases considerably.

- By increasing spindle speed, the surface roughness increases gradually up to a specific cutting speed due to the rise in friction between the two surfaces (drill-bit and bone).

- To conclude, the results from the conducted experiments can provide reference for force control and selection of rotational speed and feed rate in bone surgeries.

\section{Acknowledgment}

The authors wish to thanks Universiti Teknikal Malaysia Melaka, Universiti Kebangsaan Malaysia and the Government of Malaysia for the technical and financial support for the experiment under Research Grant (RAGS/201FKP/TK01/1B00012).

\section{References}

[1] Richards, R.G. Surfaces to control implant tissue adhesion for osteosynthesis, Folia Traumatologica Lovaniensia, Reynders, P., Burssens, P., Bellemans, J., Broos, P., Ed.; KU Leuven, 2007, p.15.

[2] Hansson, S.; Norton, M. The relation between surface roughness and interfacial shear strength for bone anchored implants. A mathematical model, Journal of Biomechanics, 1999, 32, 829836.

[3] Abouzgia, M. B., AND JAMES, D. F. Temperature rise during drilling through bone. International Journal of Oral and Maxillofacial Surgery 12, 3 (1997), 342-353.

[4] Vashishth, D.; Tanner, K.E.; Bonfield, W. Contribution, development and morphology of microcracking in cortical bone during crack propagation, Journal of Biomechanics, 2000, 33, 1169-1174.

[5] M.A. Amran, S.Salmah, N.I.S Hussein, R.Izamshah, M.Hadzley, Kasim, M.S., 2013.”Effect on machine parameters on Surface Roughness Using RSM Method in drilling process," Procedia Engineering 68. pp. 24-29.

[6] Kasim, M.S., Che Haron, C.H., Ghani, J.A., Sulaiman, M.A., 2013."Prediction Surface Roughness in High-Speed Milling of Inconel 718 under Mql Using RSM Method," MiddleEast Journal of Scientific Research. pp. 264-272

[7] W.P. Hennessy, M.T. Hillery, The design and manufacture of a drilling dynamometer for drilling Kevlar-49 reinforced composites, Proc. IMC-8, Ireland, (1991) pp. 803 \pm 816.

[8] A.Alam k., Mitrofanov A.V., Silberschmidt V.V.; 2009. Measurements of Surface Roughness in Conventional and Ultrasonically Assisted Bone Drilling, American Journal of Biomedical Sciences, 1:312-320.

[9] Onwubolo, C.G., Kumar, S., 2006. Response Surface Methodology Based Approach To CNC Drilling Operation, Journal of Materials Processing Technology 171, pp. 41-47. 
[10] Karaca F., Aksakal B., Kom M.; 2011. Influence of Orthopaedic Drilling Parameters on Temperature and Histopathology of Bovine Tibia: An in Vitro Study, Medical Engineering \& Physics, 33:1221-1227. [2] Z. Movahed, R. Junin, Z. Safarkhanlou, M. Akbar, Formation evaluation in Dezful embayment of Iran using oil-based-mud imaging techniques. J. Petrol. Sci. Eng. 121 (2014) 23-37.

[11]R Izamshah, MY Yuhazri, M Hadzley, MA Ali, S Subramonian, Effects of End Mill Helix Angle on Accuracy for Machining Thin-Rib Aerospace Component, Applied Mechanics and Materials 315, 773-77

[12]R. Izamshah, N. Husna, M. Hadzley, M. Amran, M. Shahir, M. Amri, Effects of cutter geometrical feature on machining polyetheretherketone (PEEK) engineering plastic, 2nd International Conference on Mechanical Engineering Research. Pahang, Malaysia, paper (2012), p. P157

[13] M. Amran, S. Salmah, M. Zaki, R. Izamshah, M. Hadzley, S. Sivarao, M. S. Kasim, and M. Amri, "The effect of pressure on warpage of dumbbell plastic part in injection moulding machine," Adv. Mater. Res., vol. 903, pp. 61-66, 2014.

[14] M. A. Amran, M. Hadzley, R. Izamshah, A. Hassan, S. Samsi, and K. Shahir, "Optimization of gate, runner and sprue in two-plate family plastic injection mould," AIP Conf. Proc., vol. 1217, p. 309, 2010. 